\title{
METHODS OF OPERATIONS RESEARCH
}

\section{PHILIP M. MORSE}

PROFESSOR OF PHYSICS MASSACHUSETTS INSTITUTE OF TECHNOLOGY FORMERLY DIRECTOR OF RESEARCH WEAPONS SYSTEM EVALUATION GROUP OFFICE OF THE SECRETARY OF DEFENSE
GEORGE E. KIMBALL

PROFESSOR OF CHEMISTRY COLUMBIA UNIVERSITY FORMERLY DEPUTY DIRECTOR OPERATIONS EVALUATION GROUP UNITED STATES NAVY

\section{FIRST EDITION REVISED}

\author{
Published jointly by \\ THE TECHNOLOGY PRESS OF \\ MASSACHUSETTS INSTITUTE OF TECHNOLOGY \\ and JOHN WILEY \& SONS, INC. - NEW YORK
}

CHAPMAN \& HALL, LTD. · LONDON 